\title{
Childhood obesity and the zebrafish as a model for the study of diet-induced obesity and its impact in cardiovascular system in adulthood - An overview
}

\author{
Rafael Vargas* \\ Facultad de Medicina, Universidad Antonio Nariño, Bogotá, Colombia
}

\begin{abstract}
Obesity is a serious current public health problem, which constitutes a risk factor for developing cardiovascular, endocrine, metabolic and neoplastic diseases. Inadequate nutritional intake has been argued as one of the most important factors in the development of obesity, especially the intake of high-fat diets. Obesity has been increasing in recent decades and has switched from being an adult problem to a childhood concern, with childhood obesity currently considered an epidemic. The present review shows the magnitude of this problem and the usefulness of the diet-induced obesity model in zebrafish in clarifying the impact of overfeeding and high-fat diets on excess weight gain and obesity. The evidence presented shows that the zebrafish is a useful model to study obesity and its status as a risk factor for several common chronic non-communicable diseases in humans, including metabolic syndromes, metabolic cardiopathies and heart failure.
\end{abstract}

\section{Introduction}

Obesity is a serious public health problem and is currently considered to be one of the most important risk factors for the development of various chronic health problems, such as cardiovascular, gastrointestinal, renal, endocrine, musculoskeletal and immunological diseases [1-4]. According to the World Health Organization (WHO), the prevalence of obesity tripled between 1975 and 2016. Approximately $13 \%$ of the world population presented obesity in 2016 , which represents approximately 650 million persons: $11 \%$ men and $15 \%$ women $[5,6]$. For the present review, a bibliographic search was carried out in the PubMed database, EMBASE, sciELO and the Google Scholar search engine. The terms "overfeeding", "high-fat diet", "childhood obesity", "cardiovascular risk", "diet-induced obesity" and "zebrafish heart" were combined.

Although obesity is a chronic disease that occurs predominantly in adults, childhood obesity has increased alarmingly in recent decades and is now considered a global epidemic [7-9]. In 2016, approximately 41 million children under 5 years of age were overweight or obese, and approximately half of these children lived in Asia. Considering the ages between 5 and 19 years, the prevalence of overweight and obese children rose from $4 \%$ in 1975 to $18 \%$ in 2016; more than 124 million children and adolescents are obese [5,6]. Excess weight and childhood obesity may represent a risk factor for developing chronic diseases that are difficult to manage in adults [10-12]. An exaggerated increase in adipose tissue during childhood can be a risk factor for developing health problems such as hypertension, heart failure, glucose intolerance, dyslipidemias, fatty liver disease, metabolic syndrome, diabetes mellitus 2, osteoarthritis and some types of cancer with diverse origins: endometrium, breast, ovary, prostate, liver, gall bladder, kidney and colon [13,14].

\section{Diet, nutritional balance and adipose tissue}

Obesity is a multifactorial disorder, and one of the factors that favors its development is an unbalanced diet, especially diets with high lipid content, which lead to a positive energy imbalance between caloric intake and energy expenditure [15]. It has been proposed alterations in central regulation of food intake as an origin of diet-induced obesity (DIO). In Central Nervous System (CNS) has been described anorectic and orexigenic circuits, neuropeptides, receptors and signaling pathways. Nowadays, DIO research is oriented to study the addictionlike behavioral and molecular adaptations in overeating [16-18].

In overeating an excess of calories ingested leads to storage of this excess as lipids in the fatty tissue adipocytes, where they accumulate as triglycerides and neutral lipids, and this storage favors the development of excess weight and obesity $[19,20]$.

It has been suggested that the nutritional balance in the initial stages of individual development determines its biotype in its advanced ages $[13,21,22]$. An excess of calories in the diet raises the probability of inducing an increase in the amount of adipose tissue by accumulation of lipids. There are two documented mechanisms for this increase in adipose tissue: hypertrophy or hyperplasia of adipocytes. The contribution of one mechanism or another to the development of obesity depends on various factors including age, diet, neuroendocrine regulation and genetic aspects among others [23-25]. In humans, these mechanisms could determine the likelihood for adipose tissue to expand to between 2 and $70 \%$ of body weight in response to a positive energy balance [26].

${ }^{\star}$ Correspondence to: Rafael Vargas, MD, PhD, Facultad de Medicina, Universidad Antonio Nariño, Bogotá, Colombia, Tel: 571 3177749194; E-mail: rvargas3200@hotmail.com

Key words: animal models, childhood obesity, cardiovascular risk, high-fat diet, overfeeding, zebrafish heart

Received: May 09, 2018; Accepted: May 28, 2018; Published: May 31, 2018 


\section{Relationship between adipose tissue and obesity}

Several authors suggest that in humans, an increase in the number of adipocytes in the early stages of life, due to factors including maternal obesity, gestational diabetes and nutritional alterations among others, would favor in adults a greater capacity for the accumulation of excess nutrients in the form of triglycerides and neutral fatty acids in adipocytes. This pattern implies that the probability of excess weight and obesity will be higher in individuals with a history of excess weight in childhood because they would have a greater number of adipocytes in the fatty tissue $[8,13,22,27,28]$. Adipose tissue under normal conditions is an endocrine organ that participates in the regulation of the function of various organs [29], especially cardiovascular function, through the synthesis and balanced release of proinflammatory adipokines, TNF- $\alpha$, IFN- $\gamma$, IL- 6 and anti-inflammatory cytokines IL-4, IL-5 and IL-13 [30,31]. Obesity presents a state of chronic subclinical inflammation where the synthesis and release of proinflammatory adipokines predominates, which can lead to tissue damage and multiorgan dysfunction [31]. In this condition, obesity is a cardiovascular risk factor because it can cause direct damage to the myocardium or blood vessels, cause endothelial dysfunction through proinflammatory cytokines [32], or cause indirect damage due to the overload that the perfusion of multiple organs with inflammatory lesions represents for the cardiovascular system [33-35]. However, more studies in humans are needed to clarify the mechanisms underlying these phenomena and others, which are paradoxical, such as the beneficial association between heart failure and moderate obesity $[33,36]$. To develop research on these topics, basic biomedical research with animal models is a very useful tool.

\section{Rodent models and obesity research}

Preclinical studies using models of obesity with rodents and epidemiological clinical studies show a direct relationship between fat intake and obesity $[24,37,38]$. Other studies in rodents show that weight gain is not always associated with hyperphagia and that isocaloric diets can induce visceral adipose tissue accumulation in direct proportion to the fat content of the diet [37,38]. Additionally, it has been shown that a diet rich in lipids induces subcutaneous adipose tissue proliferation and visceral adipose tissue hypertrophy, and in mice, it has been confirmed that a high-fat diet induces proliferation of adipocyte cell progenitors in subcutaneous adipose tissue [23,25]. Paradoxically, in obese mice, some antiobesity interventions, such as lipectomy, have been described that stimulate lipogenesis and adipocyte differentiation [39]. Although the obesity model in rats is considered the gold standard, the costs are high, so alternative models have been sought that would allow the development of research on this issue, especially in emerging countries where obesity is a serious public health problem. One of the alternatives for animal research is the zebrafish.

\section{Using zebrafish to study diet-induced obesity}

Although the zebrafish is a model that has become popular in recent decades for basic biomedical research due to the multiple advantages highlighted in several articles [40,41], it has not been used extensively for studies related to obesity and diet. The first studies of adipose tissue and obesity in zebrafish appeared in 2010, with information on the distribution of adipose white tissue in adult zebrafish under normal conditions [42]. Additionally, a direct relationship between a fat-rich diet and development of adipocytes was reported in live zebrafish larvae [43]. In 2010, Oka and collaborators proposed a diet-induced obesity (DIO) protocol by a diet administered over a short time in adult zebrafish [44], and in 2011, other groups proposed a test to evaluate obesity in larvae. For this, they used a vital dye, Nile red, which is incorporated into adipose tissue during tissue formation [45-47]. Both techniques are key tools for the study of this pathology in this model [44-47]. By 2014, it was reported that overnutrition stimulates the formation of beta cells in the pancreas. Increasing the number of beta cells may favor a state of hyperinsulinemia, and the excess insulin would induce changes in the metabolism favoring the accumulation of lipids in the white adipose tissue $[48,49]$. It should also be noted that insulin can act as a growth factor in different tissues and probably can induce cell proliferation and macrosomia. The increase in growth tissues in young subjects, whether stimulated by growth factors released at very early stages of development or by a persistent excess of growth factors, would favor a greater proliferation of adipocyte precursors in adipose tissue [48].

The metabolism of lipids in zebrafish is like mammals. Lipids are absorbed from dietary lipids and delivered from the intestine to the liver and from there to whole body. In the blood, the lipids are transported by lipoprotein carriers (VLDL, LDL, HDL) in the same way that in mammals $[50,51]$. Also, zebrafish has a regulatory pathway of energy homoeostasis which include a central melanocortin system that respond to leptin. In zebrafish, has been found adiponectin and adiponectin receptors, agouti-related protein, PPARs (peroxisomeproliferator-activated receptors) a lipid sensor and regulator of lipid metabolism, leptin and the regulatory lipid synthesis pathway SCAP/SREBP. Obesogenic and antiobesogenic drugs has been tested successfully in this model which suggest the conservation of key regulatory pathways of adipogenesis in zebrafish [52-57].

\section{DIO in young zebrafish and cardiovascular changes in adult zebrafish}

In 2015, Leibold and Hammerschmidt evaluated the changes presented in a DIO zebrafish model with a long-term diet administration and different fat compositions in the diets. They found an increase in the weight and body mass index (BMI) plus an increase in triglyceride levels. They describe resistance to obesity in young fish, probably due to the energy consumption in maturation processes of scales and other structures [58]. In a similar work and using a protocol of overfeeding with a high-fat diet over a long period, we show how overfeeding and the chronic intake of a high-fat diet modify somatic parameters in both young and adult zebrafish. Although we also found an initial phase of DIO resistance in young zebrafish, long-term weight gain and BMI were higher in individuals overfed since an early age [59]. Chronic administration of a high-fat diet specifically induced weight gain and higher $\mathrm{BMI}$, and the observed values meet the criteria previously established to define obesity in this model [44]. In parallel, we observed changes in the hearts of the zebrafish, including an increase in volume and changes in heart shape: fish with obesity had globular-shaped hearts, which contrasts with the triangular shape of the controls. Changes in compact and spongy myocardium were also observed [59]. This change could suggest cardiovascular overload in conditions of obesity. Cardiac structures from the embryonic to the adult stage had been previously documented in the zebrafish but under normal conditions $[60,61]$. To our knowledge, this work is the first study to show a possible relationship between overfeeding, obesity and the presence of changes at the heart level. This evidence supports hypotheses related to nutritional imbalances and the relationship between obesity and cardiovascular diseases. Similarly, Landgraf et al. (2017) showed a protocol of overfeeding and obesity to induce metabolically healthy obesity and metabolically unhealthy obesity (MHO, MUO). They confirmed and added to previous findings showing that overfeeding with high lipid 
content diets induces MUO, characterized by hypertrophy of visceral adipocytes, fat accumulation in liver and muscle tissue, hyperglycemia, hyperlipidemia, decreases in markers of lipid metabolism and increases in inflammation markers [62]. In humans, it has been proposed that obesogenic environment in which children are developing could be a high risk of morbidity and mortality from cardiovascular disease in adulthood $[63,64]$.

\section{Conclusions}

With the complete sequencing of the zebrafish genome demonstrating that it has an $80 \%$ similarity with the human genome [65], the evidence supports the hypothesis of a relationship among high lipid content diets, obesogenic pathways dysregulation and obesity; the findings appear to confirm the role of these two factors in the development of cardiovascular diseases and could be extrapolated to human beings. The results also emphasize the importance of incorporating a balanced diet at early stages of life to reduce the risk of chronic, high-cost and uncontrollable diseases in adults. Given the increasing evidence provided by the DIO zebrafish model, this model is considered a useful, low-cost model to study the relationship between obesity and non-communicable chronic diseases, clarify trigger mechanisms and propose prevention and therapeutic actions. This information in turn can be used to support public health care programs aimed at reducing the global burden of diseases related to obesity.

\section{Declarations}

\section{Funding}

This research did not receive any specific grant from funding agencies in the public, commercial, or not-for-profit sectors.

\section{Conflict of Interest}

Author declares that he has not conflict of interest.

\section{Ethical approval}

This article does not contain any studies with human participants or animals performed by any of the authors.

\section{References}

1. Visscher TL, Seidell JC (2001) The Public Health Impact of Obesity. Annu Rev Public Health 22: 355-375. [Crossref]

2. Frankel PH (2003) Obesity and cancer. $N$ Engl J Med 349: 502-504. [Crossref]

3. Bender R, Zeeb H, Schwarz M, Jöckel KH, Berger M (2006) Causes of death in obesity: relevant increase in cardiovascular but not in all-cancer mortality. J Clin Epidemiol 59: 1064-1071.

4. Guh DP, Zhang W, Bansback N, Amarsi Z, Birmingham CL, et al. (2009) The incidence of co-morbidities related to obesity and overweight: a systematic review and metaanalysis. BMC Public Health 9: 88. [Crossref]

5. Smith KB, Smith MS (2016) Obesity Statistics. Prim Care 43: 121-135. [Crossref]

6. Key TJ, NCD Risk Factor Collaboration (2017) Worldwide trends in body-mass index, underweight, overweight, and obesity from 1975 to 2016 : a pooled analysis of 2416 population-based measurement studies in 128.9 million children, adolescents, and adults.

7. Lobstein T, Baur L, Uauy R; IASO International Obesity TaskForce (2004) Obesity in children and young people: a crisis in public health. Obes Rev 5 Suppl 1: 4-104. [Crossref]

8. Cali AM, Caprio S (2008) Obesity in children and adolescents. J Clin Endocrinol Metab 93: S31-36. [Crossref]

9. Xu S, Xue Y (2016) Pediatric obesity: Causes, symptoms, prevention and treatment Exp Ther Med 11: 15-20.
10. Rössner S (1998) Childhood obesity and adulthood consequences. Acta Paediatr 87: 1-5. [Crossref]

11. Dietz WH (1998) Health Consequences of Obesity in Youth: Childhood Predictors of Adult Disease. Pediatrics 101: 518-525. [Crossref]

12. Flint AJ, Rimm EB (2006) Commentary: Obesity and cardiovascular disease risk among the young and old-is BMI the wrong benchmark? Int J Epidemiol 35: 187189. [Crossref]

13. Boney CM, Verma A, Tucker R, Vohr BR (2005) Metabolic syndrome in childhood: association with birth weight, maternal obesity, and gestational diabetes mellitus. Pediatrics 115: e290-296. [Crossref]

14. Weiss R, Dziura J, Burgert TS, Tamborlane WV, Taksali SE, et al. (2004) Obesity and the metabolic syndrome in children and adolescents. $N$ Engl J Med 350: 2362-2374. [Crossref]

15. Ravussin E, Ryan DH (2018) Three New Perspectives on the Perfect Storm: What's Behind the Obesity Epidemic? Obesity (Silver Spring) 26: 9-10. [Crossref]

16. Alsiö J, Olszewski PK, Levine AS, Schiöth HB (2012) Feed-forward mechanisms addiction-like behavioral and molecular adaptations in overeating. Front Neuroendocrinol 33: 127-139. [Crossref]

17. Chapman CD, Benedict C, Brooks SJ, Schiöth HB (2012) Lifestyle determinants of the drive to eat: a meta-analysis. Am J Clin Nutr 96: 492-497. [Crossref]

18. Jacobsson JA, Schiöth HB, Fredriksson R (2012) The impact of intronic single nucleotide polymorphisms and ethnic diversity for studies on the obesity gene FTO. Obes Rev 13: 1096-1109. [Crossref]

19. Gregg EW, Shaw JE (2017) Global Health Effects of Overweight and Obesity. N Engl J Med 377: 80-81. [Crossref]

20. Hall KD (2018) Did the Food Environment Cause the Obesity Epidemic? Obesity (Silver Spring) 26: 11-13. [Crossref]

21. Galtier-Dereure F, Boegner C, Bringer J (2000) Obesity and pregnancy: complications and cost. Am J Clin Nutr 71: 1242S-8S. [Crossref]

22. Risnes KR, Vatten LJ, Baker JL, Jameson K, Sovio U, et al. (2011) Birthweight and mortality in adulthood: a systematic review and meta-analysis. Int J Epidemiol 40: 647661. [Crossref]

23. Bourgeois F, Alexiu A, Lemonnier D (1983) Dietary-induced obesity: effect of dietary fats on adipose tissue cellularity in mice. Br J Nutr 49: 17-26. [Crossref]

24. Bray GA, Paeratakul S, Popkin BM (2004) Dietary fat and obesity: a review of animal, clinical and epidemiological studies. Physiol Behav 83: 549-555. [Crossref]

25. Joe AWB, Yi L, Even Y, Vogl AW, Rossi FMV (2009) Depot-Specific Differences in Adipogenic Progenitor Abundance and Proliferative Response to High-Fat Diet. Stem Cells 27: 2563-2570. [Crossref]

26. Hussain A, Claussen B, Ramachandran A, Williams R (2007) Prevention of type 2 diabetes: a review. Diabetes Res Clin Pract 76: 317-326. [Crossref]

27. Kaur H, Hyder ML, Poston WS (2003) Childhood overweight: an expanding problem. Treat Endocrinol 2: 375-388. [Crossref]

28. Stuart B, Panico L (2016) Early-childhood BMI trajectories: evidence from a prospective, nationally representative British cohort study. Nutr Diabetes 6: e198. [Crossref]

29. Kershaw EE, Flier JS (2004) Adipose tissue as an endocrine organ. $J$ Clin Endocrinol Metab 89: 2548-2556. [Crossref]

30. Berg AH, Scherer PE (2005) Adipose tissue, inflammation, and cardiovascular disease Circ Res 96: 939-949. [Crossref]

31. Wensveen FM, Valentić S, Šestan M, Turk Wensveen T, Polić B (2015) The "Big Bang" in obese fat: Events initiating obesity-induced adipose tissue inflammation. Eur J Immunol 45: 2446-2456. [Crossref]

32. Ouchi N, Kihara S, Funahashi T, Matsuzawa Y, Walsh K (2003) Obesity, adiponectin and vascular inflammatory disease. Curr Opin Lipidol 14: 561-566. [Crossref]

33. Bhatheja S, Panchal HB, Ventura H, Paul TK (2016) Obesity Cardiomyopathy: Pathophysiologic Factors and Nosologic Reevaluation. Am J Med Sci 352: 219-222. [Crossref]

34. Mancuso P (2016) The role of adipokines in chronic inflammation. Immunotargets Ther 5: 47-56. [Crossref]

35. Yiannikouris F, Gupte M, Putnam K, Cassis L (2010) Adipokines and blood pressure control. Curr Opin Nephrol Hypertens 19: 195-200. [Crossref] 
Vargas R (2018) Childhood obesity and the zebrafish as a model for the study of diet-induced obesity and its impact in cardiovascular system in adulthood - An overview

36. Ebong IA, Goff DC Jr, Rodriguez CJ, Chen H, Bertoni AG (2014) Mechanisms of heart failure in obesity. Obes Res Clin Pract 8: e540-548. [Crossref]

37. Boozer CN, Schoenbach G, Atkinson RL (1995) Dietary fat and adiposity: a doseresponse relationship in adult male rats fed isocalorically. Am J Physiol 268: E546-E550. [Crossref]

38. West DB, York B (1998) Dietary fat, genetic predisposition, and obesity: lessons from animal models. Am J Clin Nutr 67: 505S-512S. [Crossref]

39. Oller do Nascimento CM, Ribeiro EB, Oyama LM (2009) Metabolism and secretory function of white adipose tissue: effect of dietary fat. An Acad Bras Cienc 81: 453-466. [Crossref]

40. Briggs JP (2002) The zebrafish: a new model organism for integrative physiology. Am J Physiol Regul Integr Comp Physiol 282: R3-R9. [Crossref]

41. Lin CY, Chiang CY, Tsai HJ (2016) Zebrafish and Medaka: new model organisms for modern biomedical research. J Biomed Sci 23: 19. [Crossref]

42. Imrie D, Sadler KC (2010) White adipose tissue development in zebrafish is regulated by both developmental time and fish size. Dev Dyn 239: 3013-3023. [Crossref]

43. Flynn EJ 3rd, Trent CM, Rawls JF (2009) Ontogeny and nutritional control of adipogenesis in zebrafish (Danio rerio) J Lipid Res 50: 1641-1652. [Crossref]

44. Oka T, Nishimura Y, Zang L, Hirano M, Shimada Y, et al. (2010) Diet-induced obesity in zebrafish shares common pathophysiological pathways with mammalian obesity. BMC Physiology 10: 21. [Crossref]

45. Tingaud-Sequeira A, Ouadah N, Babin PJ (2011) Zebrafish obesogenic test: a tool for screening molecules that target adiposity. J Lipid Res 52: 1765-1772. [Crossref]

46. Minchin JE, Rawls JF (2011) In vivo analysis of white adipose tissue in zebrafish. Methods Cell Biol 105: 63-86. [Crossref]

47. Carten J, Farber S (2009) A new model system swims into focus: using the zebrafish to visualize intestinal lipid metabolism in vivo. Clin Lipidol 4: 501-515. [Crossref]

48. Maddison LA, Chen W (2012) Nutrient excess stimulates $\beta$-cell neogenesis in zebrafish. Diabetes 61: 2517-2524. [Crossref]

49. Li M, Maddison LA, Page-McCaw P, Chen W (2014) Overnutrition induces $\beta$-cell differentiation through prolonged activation of $\beta$-cells in zebrafish larvae. Am J Physiol Endocrinol Metab 306: E799-E807. [Crossref]

50. Babin PJ, Vernier JM (1989) Plasma lipoproteins in fish. J Lipid Res 30: 467-489. [Crossref]

51. Babin PJ, Gibbons GF (2009) The evolution of plasma cholesterol: direct utility or a "spandrel" of hepatic lipid metabolism? Prog Lipid Res 48: 73-91. [Crossref]
52. Hölttä-Vuori M, Salo VT, Nyberg L, Brackmann C, Enejder A, et al. (2010) Zebrafish: gaining popularity in lipid research. Biochem J 429: 235-242. [Crossref]

53. Gorissen M, Bernier NJ, Nabuurs SB, Flik G, Huising MO (2009) Two divergent leptin paralogues in zebrafish (Danio rerio) that originate early in teleostean evolution. $J$ Endocrinol 201: 329-339. [Crossref]

54. Piccinetti CC, Migliarini B, Olivotto I, Coletti G, Amici A, et al. (2010) Appetite regulation: the central role of melatonin in Danio rerio. Horm Behav 58: 780-785. [Crossref]

55. Lutfi E, Babin PJ, Gutiérrez J, Capilla E, Navarro I (2017) Caffeic acid and hydroxytyrosol have anti-obesogenic properties in zebrafish and rainbow trout models. PLoS One 12: e0178833. [Crossref]

56. Ouadah-Boussouf N, Babin PJ (2016) Pharmacological evaluation of the mechanisms involved in increased adiposity in zebrafish triggered by the environmental contaminant tributyltin. Toxicol Appl Pharmacol 294: 32-42.

57. Soengas JL, Cerdá-Reverter JM, Delgado MJ (2018) Central regulation of food intake in fish: an evolutionary perspective. J Mol Endocrinol 60: R171-R199. [Crossref]

58. Leibold S, Hammerschmidt M (2015) Long-term hyperphagia and caloric restriction caused by low-or high-density husbandry have differential effects on zebrafish postembryonic development, somatic growth, fat accumulation and reproduction. PloS One 10: e0120776. [Crossref]

59. Vargas R, Vásquez IC (2017) Effects of overfeeding and high-fat diet on cardiosomatic parameters and cardiac structures in young and adult zebrafish. Fish Physiol Biochem 43: 1761-1773. [Crossref]

60. Singleman C, Holtzman NG (2011) Heart Dissection in Larval, Juvenile and Adult Zebrafish, Danio rerio. J Vis Exp 55. [Crossref]

61. Vargas R, Vásquez IC (2016) Cardiac and somatic parameters in zebrafish: tools for the evaluation of cardiovascular function. Fish Physiol Biochem 42: 569-577. [Crossref]

62. Landgraf K, Schuster S, Meusel A, Garten A, et al. (2017) Short-term overfeeding of zebrafish with normal or high-fat diet as a model for the development of metabolically healthy versus unhealthy obesity. BMC Physiol 17: 4. [Crossref]

63. Stettler N (2007) Nature and strength of epidemiological evidence for origins of childhood and adulthood obesity in the first year of life. Int J Obes (Lond) 31: 1035 [Crossref]

64. Bridger T (2009) Childhood obesity and cardiovascular disease. Paediatr Child Health 14: 177-182. [Crossref]

65. Howe K, Clark MD, Torroja CF, Torrance J, Berthelot C, et al. (2013) The zebrafish reference genome sequence and its relationship to the human genome. Nature 496: 498503. [Crossref]

Copyright: (C2018 Vargas R. This is an open-access article distributed under the terms of the Creative Commons Attribution License, which permits unrestricted use, distribution, and reproduction in any medium, provided the original author and source are credited. 